\title{
Társadalomkép Christian Fuchs Internet és társadalom címü könyvében
}

\section{Szerzői információ:}

Kollányi Bence

Szociológus, az ELTE Társadalomtudományi Karán végezte tanulmányait médiaszociológia szakirányon. Jelenleg a Corvinus Egyetem szociológiai PhD-programjának hallgatója. 2004 óta vesz részt az ITTK munkájában, 2005-tól munkatárs. Fóbb érdeklődési területei: az információs társadalom mérhetôsége, a humán tóke és a nemzetközi versenyképességi vizsgálatok összefüggései, valamint a kormányzati információs társadalom stratégiák.

E-mail: kollanyi.bence@ittk.hu

Így hivatkozzon erre a cikkre:

Kollányi Bence. „Társadalomkép Christian Fuchs Internet és társadalom című könyvében”.

Információs Társadalom IX, 2. szám (2009): 92-98.

$=\quad$ https://dx.doi.org/10.22503/inftars.IX.2009.2.7

A folyóiratban közölt müvek

a Creative Commons Nevezd meg! - Ne add el! - Így add tovább! 4.0

Nemzetközi Licenc feltételeinek megfelelően használhatók. 
Kollányi Bence

\section{Társadalomkép Christian Fuchs Internet és társadalom címú könyvében}

Christian Fuchs tavaly megjelent Internet és társadalom (Internet and Society, Routledge) címú könyve különálló egységekból épül fel. A technológia és a társadalom viszonyát boncoló, klasszikus társadalomelméleti iskolákat feldolgozó elméleti megfontolások azonban átszövik valamennyi fejezetet, egységet teremtve a 400 oldalas kötetben.

Fuchs könyve a bevezetést és a konklúziót leszámítva nyolc tematikus egységból áll össze. A kötet első felében Fuchs szociológiai és filozófiai alapokra építve állást foglal a társadalom és a technológia viszonyával kapcsolatban. Vitába száll a technológiai determinizmussal, valamint azokkal az irányzatokkal, melyeknek a képviselói különválasztják a társadalmat és a technológiát, s az utóbbit a társadalmon kívüli eróként határozzák meg. Ezt követően a kapitalizmus változásait elemzi (,transznacionális információs kapitalizmus"), megvizsgálja a társas viszonyok új alakzatait (Web 2.0 és Web 3.0), majd az együttmúködés és a verseny egymáshoz fúződő viszonyát elemzi.

\section{Technológia és társadalom}

Az internet és a társadalom viszonyának tanulmányozása a szociális informatika (Social Informatics, SI) egyik központi kérdése. Robert Kling, a szociális informatikai iskola és a bloomingtoni Indiana Egyetemen múködő Rob Kling Kutatóközpont alapítója a következóképpen határozza meg a tudományterület feladatát: „az információs és kommunikációs technológiák (IKT) kialakulásának és felhasználásuk következményeinek interdiszciplináris megközelítésen alapuló tanulmányozása, figyelembe véve ezeknek az intézményi és kulturális környezettel való kölcsönhatásait" (Kling 1999).

A fenti definíciót továbbgondolva Fuchs két alapkérdésen keresztül kívánja a társadalom és technológia viszonyát elemezni. Azt a folyamatot, melynek során az emberi cselekvók létrehozzák a technológiát (idesorolva a technológia fejlesztésének társadalmi előfeltételeit és alapjait), különválasztja a létrehozott információs és kommunikációs technológia mind szélesebb körú használatának társadalmi következményeitól (a technológiai fejlődés társadalmi hatásától).

Ez a fajta kettôs megközelítés meghatározza egyúttal a két folyamat egymáshoz fúzôdố viszonyát is. A folyamatok kölcsönösen kapcsolódnak egymáshoz, és hatást gyakorolnak egymásra. Ezt a viszonyt Fuchs a dialektika filozófiai hagyományai alapján elemzi.

Christian Fuchs nem véletlenül fordul filozófiai múvekhez. Az 1990-es évek második felében a Bécsi Múszaki Egyetemen tanult informatikát, ahol a technológia filozófiájára specializálódott. Szakdolgozatát Az információs társadalom önszervezôdése 
címmel készítette el az ezredfordulón. Késóbb doktori disszertációját szintén az információs társadalomhoz kapcsolódó társadalomelméleti kérdésekról írta (Fuchs 2002).

Az Internet és társadalom címú könyvében a filozófiai alapok mellett a kortárs szociológiára is épít, részletesen bemutatja Anthony Giddens strukturációs elméletét. A brit szociológus által kidolgozott elmélet hozzásegíthet annak megértéséhez, hogy a társadalmi rendszerek hogyan jönnek létre, és miképpen termelődnek újra a társas viszonyokban. Giddens meghatározása szerint a strukturáció „a társadalmi viszonyok szervezôdése térben és idóben, a struktúrák dualitása alapján" (Giddens 1984).

Ahhoz, hogy megértsük Giddens megközelítését, elsóként a dualitás fogalmát kell felfejtenünk. Giddens kiindulópontja a cselekvő ember (emberi ágens) és a társas struktúra kettőssége. Érvelése szerint mindkettô elengedhetetlen a társas cselekvés megértéséhez. A cselekvók társas viszonyokban állnak helyt, miközben olyan szabályok, társadalmi normák, erőforrások határozzák meg viselkedésüket, amelyeket a társadalmi interakciók termelnek, és hoznak újra létre.

Giddens dualitásfogalmát a dualizmussal állíthatjuk szembe. A dualista kritikai relalizmus azt az álláspontot képviseli, hogy az egyénre és a társadalmi struktúrára egyaránt önálló entitásként kell tekintenünk. Az egyének közös cselekvésükkel magasabb szintú, az egyén felett és rajta kívül álló minôséget hoznak létre. A struktúra tehát az egyénen kívül lelhetố fel, és sok esetben kényszerítố erejú.

Ezzel szemben Giddens azt az álláspontot képviseli, hogy a struktúrák nem létezhetnek „a fejeken kívül”, azaz az egyénhez viszonyítva nem tekinthetjük azokat külsốdlegesnek. Giddens szabályokról és erôforrásokról (rules and resources) beszél, amelyek az egyének társas tapasztalatain keresztül alakulnak ki, illetve halmozódnak fel. A fenomenológiai megközelítés szerint ez a tudás egyfajta praktikus ismeret, amely a mindennapi cselekedetekben, rutinokban nyilvánul meg. Giddens szerint az ember társas világa az egyének közötti interakciók során termelő́dik újra.

Az emberi cselekvók Giddens felfogásában kölcsönösen megértik egymást, annak ellenére, hogy eltérő struktúrákkal rendelkeznek. Éppen az említett szabályok és erőforrások teszik lehetővé, hogy a társas helyzetekben megértsük egymást, illetve magukat a társas helyzeteket koordináljuk. Az ezt elốsegítố (társadalmi) struktúrák tehát belsók, bizonyos mértékig eltéróek és önmagukat termelik újra, biztosítva a struktúra fennmaradását, miközben lehetővé teszik a folyamatos változást.

Giddens elméletét többen is felhasználják a technológia és a társadalom viszonyának elemzéséhez. Orlikowski például a strukturációra építve elemzi a technológia és a társadalom viszonyát (Orlikowski 1992). A dualitás alapján érvényteleníti azokat a korábbi megközelítéseket, amelyek a technológiát kizárólag objektív külsố eróként írták le, továbbá azokat az elemzéseket is, amelyek nem foglalkoznak a technológia hatásaival, arra hivatkozva, hogy maga a technológia kizárólag társadalmilag konstruált (socially constructed).

\section{Luhmann - és a társadalom úiratermelödése}

Christian Fuchs a technológiára önálló alrendszerként tekint, a technológia és a társadalom kapcsolatát bonyolult keretben elemzi. A technológia és a társadalom viszonyának vizsgálatát megelôzóen ezért elsóként az egyén és a társadalom viszonyát, 
illetve a társadalom újratermelődését tárgyalja. Részben önálló, eredeti társadalomelméletét igyekszik a szociológiai diskurzusban elhelyezni, következésképpen a saját megközelítését más elméletekhez viszonyítva építi fel.

Fuchs már egy öt évvel korábban megjelent cikkében (Fuchs 2003) felhívja a figyelmet arra, hogy az internet nem tekinthető pusztán egymáshoz kapcsolt számítógépek hálózatának. A világháló ugyanis emberi kapcsolatokra, emberek által termelt, kiválasztott és értelmezett tudásra épül. Az internetet használó cselekvô egyének pedig újra és újra megerôsítik ezt a hálózatot. Fuchs a társas-technológiai rendszer folyamatainak elméleti keretéhez felhasznált elemek egy részét - például az autopoieszisz fogalmát Luhmanntól veszi át, miközben folyamatosan vitatkozik a német szociológussal.

Luhmann az autopoieszisz fogalmát egy chilei biológus szerzốpárostól kölcsönzi. Humberto Maturana és Francisco Varela az 1970-es évek elején közölt tanulmányukban definiálják az autopoieszisz fogalmát (Maturana és Varela 1973). Luhmann egy késóbb megjelent publikációjuk alapján mutatja be az „autopoieszisz” kifejezést, amely az ő értelmezésében azt jelenti, hogy „[...] egy rendszer a saját múveleteit csak a saját múveleteinek hálózata révén tudja létrehozni. A saját múveletek hálózatát pedig ismét ezek a múveletek hozzák létre."

Mint jeleztük, az autopoieszisz fogalmat a szociológiába Luhmann vezette be. Az autopoieszisz a szociális rendszerekben csak abban az esetben valósul meg, ha teljesül az az előfeltétel, miszerint a múvelet vagy abbamarad, vagy önmagával folytatódik. Luhmann szerint a kommunikáció az a múvelettípus, amelyre a fenti feltétel teljesül: „Szociális rendszer akkor jön létre, ha a kommunikáció kommunikációból alakul ki” (Luhmann 2006).

Fuchs Luhmann 1988-ban megjelent kötete alapján idézi az autopoieszisz és a kommunikáció viszonyát: „A társadalmi rendszerek esetében a kommunikáció az a sajátos mód, ahogy az autopoietikus reprodukció végbemegy. A társadalmi rendszer kommunikációból épül fel, amely rekurzívan állítódik elő, és a kommunikációs hálózat által reprodukálódik, és amely nem létezhet ezen hálózaton kívül” (idézi Fuchs).

Luhmann szerint a társadalom alrendszerei zárt kommunikációs formák, hálózatok, amelyek közül mindegyiknek megvannak a saját bináris kódjai. Ezek a kétértékú kódok az egyes fogalmakhoz kapcsolódó ellentétpárokat jelölik, amelyek az adott alrendszer határait megszabják.

Ilyen például a jog esetében a legális és az illegális, vagy a tudomány alrendszerében az igaz és a hamis, a morális jó és rossz megkülönböztetése. Ebben a megközelítésben az egyes alrendszerek egymás környezetének részei. Sok esetben ugyan hatással vannak egymásra, , az egyes alrendszerek befolyásolhatják egymást, mégis minden egyes alrendszer önálló, autonóm módon létezô" (Fuchs 2008). Fuchs több ponton is vitatkozik Luhmann-nal. Legfontosabb kritikája arra vonatkozik, hogy Luhmann elmélete nem tekinti cselekvóképesnek az egyént, a cselekvoót csupán rendszerszinten értelmezi. Kritikájában sok elemet Anthony Giddenstól vesz át. 


\section{Középpontban az emberi cselekvő}

Az ember szerepe a társadalomban központi kérdés Fuchs számára, aki a társadalmat alkotó egyénekre minden esetben cselekvő, aktív szereplóként tekint. Értelmezésében a strukturalisták és a funkcionalisták a társadalmi struktúrák kényszerítố erejét hangsúlyozzák, amely hatással van az egyéni cselekvókre (aktorokra) és azok cselekedeteire. A dualisztikus társadalomelméletek ezzel szemben a cselekvóket és a társadalmi struktúrákat egymástól függetlenként határozzák meg, és azt emelik ki, hogy a cselekvók önálló pszichés rendszerek, és nem tartoznak a társadalmi rendszerszinthez. A dialektikus megközelítések megpróbálják elkerülni ezt a megkülönböztetést, és az aktorokat és a társadalmi struktúrákat egymással összefüggésben értelmezik.

Fuchs (2008) szerint a funkcionalista és strukturális megközelítésból kiinduló gondolkodók „nem képesek az emberre érvelni képes, tudással rendelkező cselekvőként tekinteni”, és amellett érvelnek, hogy a társadalom és az intézmények meghatározott funkciók betöltésére jöttek létre, ami az esetek egy részében „alany nélküli történelemhez” (subjectless history) vezet. A „alany nélküli történelem” kifejezést Fuchs minden bizonnyal Louis Althussertól veszi át, akire egyébként a könyv késóbbi fejezeteiben maga is utal.

Összefoglalva elmondható, hogy Fuchs számára az egyén társas, öntudatos, kreatív és reflektív entitás, nyelvet és szimbólumokat használ, saját történelmét alakítja, és képes a szabadság és az autonómia felé törekedni.

\section{A technológiai determinizmustól a dialektikus megközelítésig}

Fuchs könyvében élesen és pontosan bírálja a technológiai determinizmust. A technológiai determinizmus ugyanis - hasonlóan a történelmi materializmushoz - nem veszi figyelembe a cselekvő embert. Az elmúlt évtizedekben minden kétséget kizáróan mélyreható változások zajlottak le, s ezek a változások az „információs társadalom” paradigmával foglalkozó kutatók szerint érintették a társadalom alapvető múködését. A technológiának a társadalom formálódásában játszott szerepét azonban már lényegesen eltérôen látják, értelmezik a különböző iskolák képviselói. A technológiai determinizmus két szempontból is szúkítő fogalom. Először is az irányzat hívei hajlamosak a változásokat kizárólag a technológiák elterjedésével összefüggésben elemezni. Másodszor - és Fuchs is ezt a mozzanatot emeli ki könyvében -, a technológiai determinizmus a technológiát külsố társadalomformáló erônek tekinti. Ez lényegében azt jelenti, hogy a technológia nem része a társadalomnak, objektív külső erő, kutatóként pedig az a célunk, hogy megértsük a technológiának a társadalomra gyakorolt hatását.

Ezzel a felfogással szemben állnak azok az iskolák, amelyeknek a képviselói kizárólag társadalmi kontextusban, a társas viszonyok felól értelmezik a technológiával összefüggő változásokat. Fuchs példaként a társadalmi konstruktivizmust (social constructivism), a cselekvóhálózat-elméletet (actor network theory), a neomarxista technológiakritikát és a cultural studies megközelítését említi. Ezek az iskolák a technológiához az emberek, illetve a társadalom felól közelítenek. A technológiákat szerintük emberek találják fel, gyakorlati megvalósításukon is emberek dolgoznak, továbbá hasz- 
nálatuk is az emberekhez kapcsolódik, s ennek megfelelően a technológia fejlődését minden esetben a társadalmi környezet formálja, alakítja, s a technológia a társadalomtól elválasztva nem értelmezhető.

Christian Fuchs válasza a technológia egymással szemben álló kétféle értelmezésére a dialektikus megközelítés. Eszerint a technológia és a társadalom viszonyát csak dinamikus folyamatként értelmezhetjük, így szabadulhatunk meg a technikai determinizmus és a technológia formálódását csakis társadalmi kontextusban értelmezó konstruktivizmus egyoldalúságától egyaránt.

\section{A kooperáció mint az új társadalmi forma motoria}

Fuchs másik központi fogalma a kooperáció. A fogalom meghatározásánál Marx munkásságából indul ki. Marx a kooperációt úgy határozta meg $A$ tóke címú múvében, hogy számos munkás egymás mellett, együtt dolgozik, függetlenül attól, hogy egy és ugyanazon a feladaton vagy pedig több különbözô, de egymáshoz kapcsolódó részfeladaton dolgoznak.

Fuchs elfogadja Marx meghatározását, de kibővíti azt. Úgy véli, hogy Marx kooperációfogalma nem csupán a munka világára vonatkozik, hiszen az együttmúködés (kooperáció) az emberi társadalom egyik legalapvetóbb mozgatórugója.

A kooperáció jellemzésére több olyan fogalmat is felhasznál, amelyek jellemzóen a hálózati gazdasággal, illetve az információs társadalommal foglalkozó irodalomban használatosak. Az intenzív kommunikáció, a munkafolyamatok újraszervezése és az interkonnektivitás is mind megjelenik például Manuel Castells munkáiban (Castells 2005).

Fuchs megfogalmazása szerint „a kooperáció a kommunikációnak egy olyan speciális típusa, amelyben a szereplók osztják egy adott társadalmi jelenség értelmezését, összehangoltan hasznosítják a rendelkezésre álló eróforrásokat, aminek következtében új minőségú rendszer jön létre (emergencia valósul meg), mindkét fél tanul, a folyamat valamennyi szereplő javára válik és mindenki kényelmesen érzi magát abban a társas rendszerben, amelyet közösen hoznak létre.

Láthattuk, hogy Fuchs szerint a társas interakciókban új kvalitások és struktúrák jönnek létre, amelyek nem magyarázhatók az egyéni szintekkel. Fuchs az emergenciával kapcsolatban fontosnak tartja, hogy a struktúrák alulról felfelé (bottom-up) épülnek ki, és bennük olyan rendszerszint jön létre, amely nem redukálható pusztán a struktúrát alkotó elemek összességére (hasonlóan ahhoz, ahogyan a sejtek összessége alkotja az élő szervezetet). A körkörös folyamatnak a jelölésére pedig, melynek során a társadalmi rendszer önszervezôdoó módon újra és újra létrehozza a társadalmi struktúrákat, Hofkirchner „re-kreáció” terminusát alkalmazza (Hofkirchner 1998).

\section{Információs társadalom és annak kritikája}

Fuchs kötetének a címe is azt jelzi, hogy az információs és kommunikációs technológiák elterjedésének fényében kívánja elemezni a jelenkori társadalmat. Az információs társadalommal foglalkozó munkákban rendre felmerül, hogy a technológiák 
elterjedése és az információk szerepének növekedése vajon új társadalmi minôséget hoz-e létre. Fuchs elóször azokat a szerzóket mutatja be, akik amellett érvelnek, hogy a korábbi társadalmaktól gyökeresen eltérố társadalomban élünk.

A néhány oldalas leltár felsorolja az információs társadalommal foglalkozó legfontosabb alapmúveket. Az 1960-as évekre datálható kezdetek, Fritz Machlup tudásiparkoncepciója után megjelennek Peter Drucker és Marc Porat késóbbi múvei. A fogalmi körképben Daniel Bell 1973-ban publikált könyve és Alain Touraine néhány évvel korábbi munkája kapcsán felvillan a posztindusztriális társadalom képe. A sort Alvin Toffler „harmadik hulláma”, a Castells-trilógia és számos más olyan társadalomtudományi elemzés folytatja, amelyek új minôségról, új társadalmi formákról szólnak.

Fuchs az információs és kommunikációs technológiák elterjedésével alapjaiban megváltozó társadalom víziójával a technológiai változásokat elemzố neomarxisták kritikáját állítja szembe. Az idesorolható szerzók többsége tagadja, hogy az IKT elterjedésével, az információ felértékelódésével új társadalmi forma alakult ki. Ahogy Frank Webster brit szociológus megfogalmazta: „Amennyiben csupán az információ mennyisége nô meg, nehéz megérteni, hogy miért sugallja bárki is azt, hogy valami teljesen új dolog áll előttünk" (idézi Fuchs, 2008).

Christian Fuchs késóbb amellett érvel, hogy a neomarxista megközelítések elsősorban a kapitalizmus átalakulását, „hatékonyabb” múködését emelik ki, s így elkerülik azt a csapdát, amelyet az „információs társadalom” és más hasonló fogalmak rejtenek magukban. A korábban említett szerzók ugyanis kivétel nélkül új társadalmi formaként írták le a jelenkori társadalmat, miközben a legkülönbözóbb terminusokat használták annak megnevezésére: az információs társadalom mellett többek között tudástársadalomról, hálózati társadalomról, posztmodern és posztindusztriális társadalomról írtak.

Ezzel szemben a neomarxisták „digitális kapitalizmusról” beszélnek. Fuchs Dan Schillert idézi, aki szerint a hálózatok általánossá tették a kapitalista gazdaság társadalmi és kulturális jellemzóit. A Michael Dawson és John Bellamy Foster által használt „virtuális kapitalizmus” kifejezés arra utal, hogy az információs technológiák elterjedésének hatására a cégek magasabb profitra tesznek szert, miközben a piacokon soha nem látott koncentráció valósul meg. Wolfgang Fritz Haug megközelítése, a „,high-tech kapitalizmus" a technológiai változások kapcsán a termelékenységet és a globalizáció kiterjedését hangsúlyozza.

\section{Záró gondolatok}

Fuchs 2008-ban megjelent kötete fontos írás, amelyet a technológia és a társadalom komplex viszonyának megértéséhez mindenképpen érdemes elolvasni. Számos olyan kérdést tisztáz, amely végiggondolása nélkül nem érdemes az információs társadalommal kutatóként foglalkozni. A könyv ugyanakkor eróteljesen ideologikus, élesen szembefordul a kapitalizmus jelenlegi formájával. E recenzió szerzôje nem ért egyet Fuchsszal abban, hogy egy új társadalmi minőség felismerése, az információs társadalom fogalmának használata a jelenlegi rendszer feltétlen elfogadását jelentené. Az információ termelését, feldolgozását és megosztását középpontba helyezố és a disz- 
kontinuitást hangsúlyozó megközelítések (köztük az „információs társadalom” vagy a „tudástársadalom” tételezése) nem feltétlenül jelentik azt, hogy kizárólag az IKT elterjedése változtatta volna meg az ipari társadalmakat, mint ahogy azt sem jelenti, hogy korábban az információnak nem lett volna jelentốs szerepe. A baloldali kritikai megközelítések és az „információs társadalom”, illetve az azt tanulmányozó társdiszciplínák szembeállítása részben érthető, de a konklúzió nem vezet közelebb a jelenkori társadalmi változások megértéséhez.

\section{Irodalom}

Castells, Manuel 2005: A hálózati társadalom kialakulása. Budapest, Gondolat-Infonia. Fuchs, Christian 2008: Internet and Society. Social Theory in the Information Age. Routledge Research in Information Technology and Society Series, Number 8. New York, Routledge.

Fuchs, Christian 2003: The Internet as a Self-Organizing Socio-Technological System. Human Strategies in Complexity Research Paper.

Giddens, Anthony 1984: The Constitution of Society: Outline of the Theory of Structuration. Berkeley, University of California Press.

Hofkirchner, Wolfgang 1998: Emergence and the logic of explanation. Acta Polytechnica Scandinavica, Mathematics, Computing and Management in Engineering Series, 91: 2330.

Kling, Rob 1999: What is Social Informatics and Why Does it Matter? D-Lib Magasine, V. évfolyam, 1. szám. http://www.dlib.org/dlib/january99/kling/01kling.html

Luhmann, Niklas 2006: Bevezetés a rendszerelméletbe. Társadalomtudományi Könyvtár sorozat. Budapest, Gondolat Kiadó.

Maturana, Humberto - Varela, Francisco 1991: Autopoiesis and Cognition: the Realisation of the Living. 1st edition. Springer.

Orlikowski, W. J. 1992: The duality of technology: rethinking the concept of technology in organizations. Organization Science, Vol. 1. No. 3, 398-427. 